\title{
Factors influencing consumer's buying decision towards aroma milk in Coimbatore district of Tamil Nadu
}

\author{
K Dhanya \& N Venkatesa Palanichamy
}

Journal of Agriculture and Ecology

ISSN: 2456-9410

Volume: 7

Journal of Agriculture and Ecology (2019) 7: 64-72

http://doi.org/10.53911/JAE.2019.7107

Volume-7 (June, 2019)

ISSN: 2456-9410

\section{Journal of Agriculture \\ and Ecology}

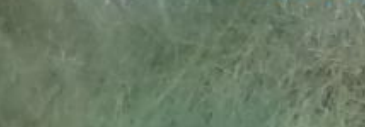




\title{
Factors influencing consumer's buying decision towards aroma milk in Coimbatore district of Tamil Nadu
}

\author{
K Dhanya $\square^{1} \&$ N Venkatesa Palanichamy ${ }^{2}$ \\ ${ }^{1}$ PG Scholar. Department of Agriculture and Rural Management, Tamil Nadu Agricultural University, \\ Coimbatore - 641003. \\ ${ }^{2}$ Professor, Department of Agriculture and Rural Management, Tamil Nadu Agricultural University, \\ Coimbatore - 641003. \\ Corresponding author: K Dhanya, Email: dhanyakandasamy@gmail.com
}

\begin{tabular}{l} 
Article Info \\
\hline Article history \\
Received: 03 September \\
2018 \\
Accepted: 10 September \\
2018 \\
Available online: 15 June \\
2019 \\
\hline
\end{tabular}

$\begin{array}{lr}\text { Key } & \text { Words: } \\ \text { Consumer's } & \text { preference, } \\ \text { consumer's } & \text { attitude, } \\ \text { buying } & \text { behaviour, } \\ \text { market and pricing. }\end{array}$

\begin{abstract}
India is the largest milk producing country since 1997 and also the largest consumer of dairy products. In India, the co-operatives and private dairies have access to only $20 \%$ of the milk produced. Approximately, $34 \%$ of the milk is sold in the unorganized market whereas $46 \%$ is consumed locally. Players are emphasizing on offering the consumer better quality differentiated milk products. Consumers are looking for more healthier dairy options. This study analysis the major factors influencing the buying decision of Aroma milk among the consumers in Coimbatore district, Tamil Nadu. The major attributes included for determining the decision behaviour were quality, health consciousness, price, packaging, availability and door delivery. The results concluded that the consumers prefer to purchase Aroma milk on the basis of quality. Also, it is certain that, people are health conscious about the product they purchase in day-to-day life.
\end{abstract}

Copyright (C2019 Dhanya et al., This is an open access article published under the terms of the Creative Commons Attribution License, which permits unrestricted use, distribution, and reproduction in any medium, provided the original work is properly cited.

Preferred citation: Dhanya K \& Venkatesa Palanichamy N. 2019. Factors influencing consumer's buying decision towards aroma milk in Coimbatore district of Tamil Nadu. Journal of Agriculture and Ecology, 7: 64-72; http://doi.org/10.53911/JAE.2019.7107.

\section{Introduction}

India has been showing a tremendous milk production over these 40 years and now indeed, it has the world's substantial dairy industry in terms of milk production with the estimation of total milk output as 165 million tonnes during the Financial Year 2016-17 (National Dairy Development Board) holding more than $16 \%$ contribution to the World's total milk production. Of this, Uttar Pradesh is the massive contributor of $17.6 \%$ and Tamil
Nadu clenches ninth position by contributing $5.03 \%$. The Indian GDP exhibits a decline phase in agriculture and livestock sector from 34.2 percent and 4.82 percent in $1980-81$ to 17.46percent and 4.43percent in 2015-16 (National Dairy Development Board), where as the share of livestock has been subscribing an increase in Indian agricultural GDP from 13.88 percent in $1980-81$ to 27.25 percent in 2012-13 (National Accounts Division). Getting the tag of World's largest milk 
producer, India also clutches the proud of being the largest consumer of dairy products. The consumption of dairy products' has been exponentially growing due to its rich nutritional qualities in the country, and in regards with the facts and figures, India's milk production will further grow at a CAGR of around 14\% between 2015-16 and 2021-22.

Kariyawasam et al. (2006) studied consumer attitude and perception towards a milk product in Sri Lanka and observed that consumers tended to purchase tetra-pack considering the attributes included in value and package subsets mainly, including purity, appearance, size, convenience and informational labeling etc. However, consumers did not believe that it enhanced those attributes included in 'food safety' and 'nutritional' subsets. The statistical outcome showed that age, gender, level of education and income had a significant impact on this behavior. In a another study conducted by Rangasamy \& Dhaka (2008) on marketing efficiency of Dairy Products for Co-operative and Private Dairy Plants in Tamil Nadu and the study aimed at comparing the marketing of milk and milk products by dairy plants of cooperative and private sectors in Tamil Nadu and recorded that the marketing cost for toned milk was same in both sectors whereas, it was higher for other milk in the co-operative dairy plant. The study also found that value addition in dairy products should be done without compromising quality and consumer-oriented market research and development should be accorded greater attention. Therefore, the present study was designed to identify the factors influencing the buying behavior of Aroma dairy products.

\section{Materials and Methods}

Research Design: Stratified simple random samplings were used for data collection and in total 120 respondents were selected out of which 75 were Aroma product buyers and 45 were non-buyers.

Method of Data Collection: Primary data was collected through well-structured interview schedule regarding socio-economic characteristics, buying behavior and constraints faced by the consumers. Secondary data related to production of milk, demography were collected from various websites, publishes and unpublished sources. Tools used for analysis: The Factor Analysis statistical tools were used for analysis and interpretation of the data where the observed data values are expressed in the form of functions of a number of possible causes in order to find which are the most important.

\section{Results and Discussion}

Consumer buying decision is affected by various factors that determine the product and brand preference of consumers. Marketing begins with identification of consumer needs and wants and trying to fulfil the through various elements of marketing mix. Product knowledge is more important in case of both producers and consumers which will affect the buying behaviour of the consumers.

\section{Rotated Factor Matrix}

The rotated factor matrix for the attributes of Aroma Milk relating to the buying behaviour is given in Table1. 
Table1. Rotated component matrix

\begin{tabular}{|c|c|c|c|c|c|c|c|}
\hline \multirow{2}{*}{$\begin{array}{l}\text { S. } \\
\text { No }\end{array}$} & \multirow{2}{*}{ Factors Influencing Buying Behavior } & \multicolumn{6}{|c|}{ Component } \\
\hline & & 1 & 2 & 3 & 4 & 5 & 6 \\
\hline 1. & Due to good Aroma of milk. & 0.988 & 0.073 & 0.013 & 0.001 & 0.046 & 0.001 \\
\hline 2. & It is having essential fat contents. & 0.987 & 0.072 & -0.001 & -0.015 & 0.034 & 0.007 \\
\hline 3. & It is ensuring perfect milk consistency & 0.987 & 0.076 & 0.000 & -0.001 & 0.047 & 0.003 \\
\hline 4. & It has unique taste. & 0.985 & 0.089 & 0.009 & -0.007 & 0.048 & 0.005 \\
\hline 5. & It is suitable for all age group. & 0.984 & 0.062 & 0.010 & 0.002 & 0.044 & -0.001 \\
\hline 6. & It has no adulteration. & 0.982 & 0.068 & 0.008 & -0.007 & -0.043 & 0.004 \\
\hline 7. & It is rich with protein content. & 0.104 & 0.722 & -0.111 & -0.004 & -0.245 & 0.179 \\
\hline 8. & It is suitable for health conscious consumers. & 0.149 & 0.637 & 0.149 & -0.105 & 0.165 & 0.029 \\
\hline 9. & $\begin{array}{l}\text { It is adopted by patients (with diabetics, high } \\
\mathrm{BP} \text { and heart problem, etc.) }\end{array}$ & 0.201 & 0.586 & -0.012 & -0.004 & 0.289 & -0.014 \\
\hline 10. & $\begin{array}{l}\text { Contains required calories for pregnant } \\
\text { women, babies and teen ages \& Children. }\end{array}$ & 0.109 & 0.421 & 0.040 & 0.124 & 0.003 & -0.260 \\
\hline 11. & It has reasonable price. & 0.017 & 0.074 & 0.761 & -0.139 & -0.054 & 0.138 \\
\hline 12. & Hike in price is suitable for quality. & 0.048 & -0.107 & 0.751 & 0.194 & 0.134 & 0.001 \\
\hline 13. & $\begin{array}{l}\text { Price in comparison to other brands is } \\
\text { satisfactory. }\end{array}$ & -0.078 & 0.235 & 0.455 & 0.245 & -0.153 & -0.360 \\
\hline 14. & Products delivered at right time. & -0.013 & 0.017 & 0.005 & 0.705 & 0.053 & -0.178 \\
\hline 15. & Regular availability. & 0.004 & -0.048 & 0.100 & 0.701 & -0.094 & 0.123 \\
\hline 16. & Door Step delivery. & 0.048 & -0.017 & 0.115 & -0.166 & 0.807 & 0.028 \\
\hline 17. & Door delivery timing is consistent. & 0.095 & 0.290 & -0.153 & 0.231 & 0.524 & 0.019 \\
\hline 18. & $\begin{array}{l}\text { Quality of packing in terms of proper sealing } \\
\text { and no leakages }\end{array}$ & -0.061 & -0.027 & 0.162 & -0.080 & -0.043 & 0.770 \\
\hline 19. & $\begin{array}{l}\text { Requirement item are correctly printed on the } \\
\text { label. }\end{array}$ & 0.029 & 0.0358 & -0.173 & 0.303 & 0.167 & 0.499 \\
\hline
\end{tabular}

Extraction Method: Principal Component Analysis; Rotation Method: Varimax with Kaiser; Rotation converged in7iterations.

The variable defining Factor1 with buying behaviour is mentioned below in the their factor loading and communality for the Table 2. given attributes of Aroma Milk relating to the Table2. Factor1-quality

\begin{tabular}{clccc}
\hline S. No & \multicolumn{1}{c}{ Variable } & Factor Loading & $\begin{array}{c}\text { Communality } \\
\left(\mathrm{H}^{2}\right)\end{array}$ & $\begin{array}{c}\text { CRONBACH'S } \\
\text { Alpha }\end{array}$ \\
\hline 1. & $\begin{array}{l}\text { Due to good Aroma of } \\
\text { milk. }\end{array}$ & 0.988 & 0.984 & \\
2. & $\begin{array}{l}\text { It is having essential fat } \\
\text { contents. }\end{array}$ & 0.987 & 0.981 & 0.729 \\
3. & $\begin{array}{l}\text { It is ensuring perfect milk } \\
\text { consistency }\end{array}$ & 0.987 & 0.980 & \\
4. & It has unique taste. & 0.985 & 0.979 & \\
5. & It is suitable for all age & 0.984 & 0.973 &
\end{tabular}




\section{group. \\ 6. It has no adulteration. \\ 0.982 \\ 0.971}

$\mathbf{H}_{\mathbf{0}}$ 1: The first hypothesis is proved by the fact

Among the attributes of Aroma Milk, the attributes such as' good aroma of milk', 'essential fat contents', 'perfect milk consistency', 'unique taste', 'suitable for all aged group', 'no adulteration' are categorized under "Quality". All these six attributes has high communality indicating that the attributes within the factor 1 have very high association among them. These attributes explain this factor to the extent of 72.90 percent. that consumers give high importance to the quality of the product, either knowingly or unknowingly appraises the fluid milk for its quality.

The variables defining factor 2 with their factor loading and communality for the Attributes of Aroma milk relating to the buying behaviour is given below in the Table3.

Table 3 Factor-health

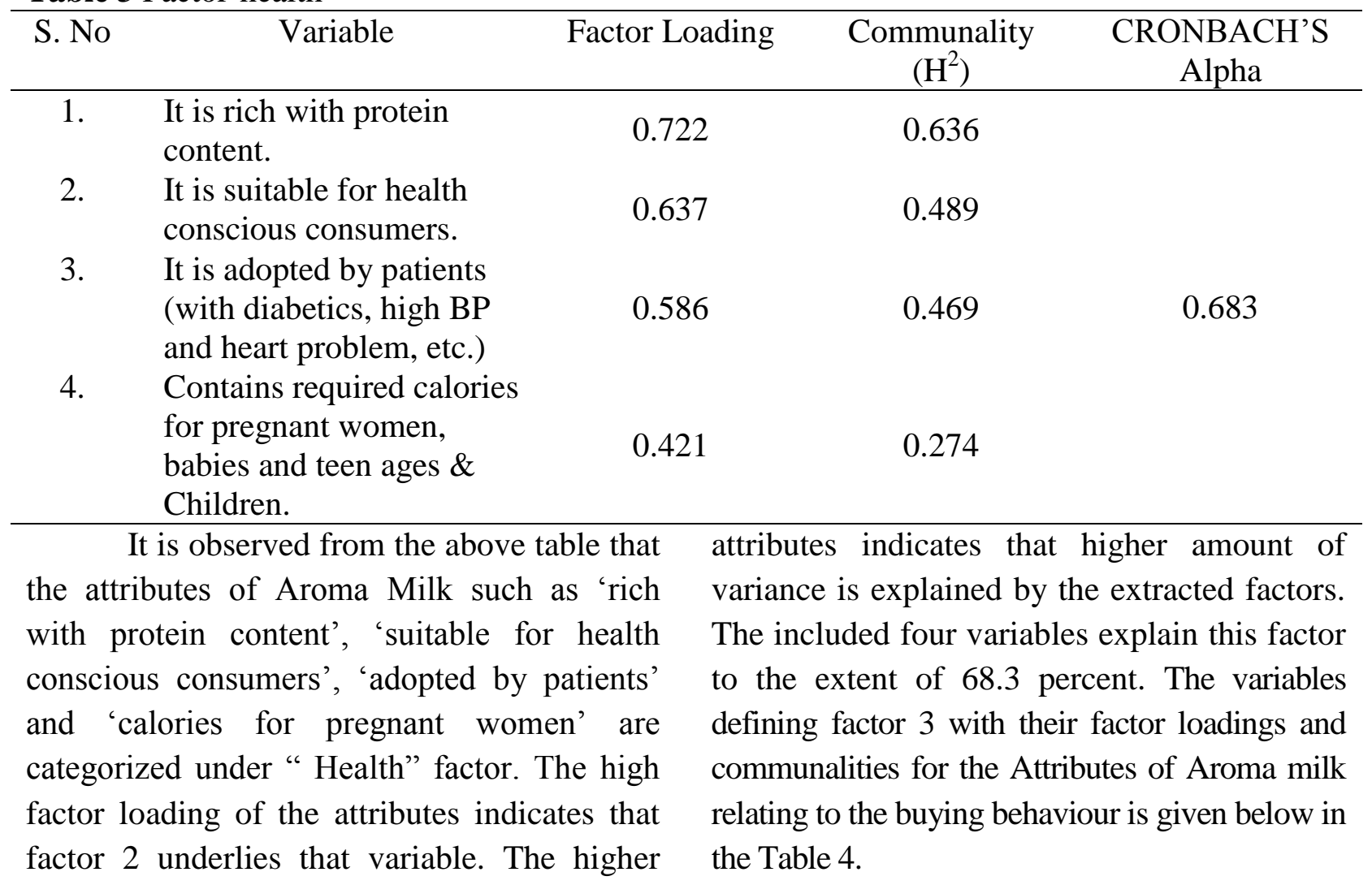
value of the communality for the four Table 4. Factor- price

\begin{tabular}{ccccc}
\hline S. No & Variable & Factor Loading & $\begin{array}{c}\text { Communality } \\
\left(\mathrm{H}^{2}\right)\end{array}$ & $\begin{array}{c}\text { CRONBACH'S } \\
\text { Alpha }\end{array}$ \\
\hline 1. & It has reasonable price. & 0.761 & 0.626 & 0.710 \\
\cline { 3 - 4 }
\end{tabular}


2. Hike in price is suitable for quality.

3. Price in comparison to other brands in the market is satisfactory.
0.751

0.455
0.633

0.481
It is observed from the above table that the attributes of Aroma milk such as 'reasonable price', 'hike in price suitable for quality' and 'price comparison to other brand' constituted factor 3 are characterized as "Price". The higher factor loading of the attributes indicate that factor 3 under lies that variable. The higher value of communality for the three attributes indicates that higher amount of variance is explained by the extracted factors. The included four variables explain this factor to the extent of 71.0 percent. The variables defining factor 4 with their factor loadings and communalities for the Attributes of Aroma milk relating to the buying behaviour is given below in the Table 5 .

Table 5. Factor- availability

\begin{tabular}{|c|c|c|c|c|}
\hline S. No & Variable & Factor Loading & $\begin{array}{c}\text { Communality } \\
\left(\mathrm{H}^{2}\right)\end{array}$ & $\begin{array}{l}\text { CRONBACH'S } \\
\text { Alpha }\end{array}$ \\
\hline 1. & $\begin{array}{l}\text { Products delivered at right } \\
\text { time. }\end{array}$ & 0.705 & 0.532 & 0.663 \\
\hline 2. & Regular availability. & 0.701 & 0.528 & \\
\hline \multicolumn{5}{|c|}{$\begin{array}{l}\text { Among the variables of motivation, the the factor } 4 \text { have very high association among } \\
\text { es such as 'delivered at right time', them. The included two variables explain thi } \\
\text { availability' with high factor loading on factor to the extent of } 66.30 \text { percent. The } \\
t \text { are characterized as 'Availability'. The variables defining factor } 5 \text { with their factor } \\
\text { factor loading of the variables indicate loading sand communalities for the Attributes } \\
\text { ctor } 4 \text { under lies that variable. The of Aroma milk relating to the buying } \\
\text { value of communality for the two behaviour is given below in the Table } 6 \text {. }\end{array}$} \\
\hline
\end{tabular}
attributes indicates that the variables within Table 6 Factor- door delivery

\begin{tabular}{clccc}
\hline S. No & \multicolumn{1}{c}{ Variable } & Factor Loading & $\begin{array}{c}\text { Communality } \\
\left(\mathrm{H}^{2}\right)\end{array}$ & $\begin{array}{c}\text { CRONBACH'S } \\
\text { Alpha }\end{array}$ \\
\hline 1. & $\begin{array}{l}\text { Door Step delivery. } \\
\text { Door delivery timing is } \\
\text { consistent. }\end{array}$ & 0.807 & 0.696 & 0.693 \\
\hline
\end{tabular}

It is observed from the table that, the attributes of Aroma milk such as 'door step delivery' and 'door delivery time' constituted factor 5 are characterized as "Door Delivery". The highest factor loading of the attributes indicate that factor 5 underlies that variable. The higher value of communality for the two attributes indicates that higher amount of variance is explained by the extracted factors. The included two variables explain this factor to the extent of 69.3 percent. The variables defining factor 6 with their factor loadings and communalities for the attributes of Aroma milk relating to the buying behaviour is given below in the Table 7 . 
Table 7. Factor-packaging

\begin{tabular}{clccc}
\hline $\begin{array}{c}\text { S. } \\
\text { No }\end{array}$ & \multicolumn{1}{c}{ Variable } & $\begin{array}{c}\text { Factor } \\
\text { Loading }\end{array}$ & $\begin{array}{c}\text { Communality } \\
\left(\mathrm{H}^{2}\right)\end{array}$ & $\begin{array}{c}\text { CRONBACH'S } \\
\text { Alpha }\end{array}$ \\
\hline 1. & $\begin{array}{l}\text { Quality of packing in terms of proper } \\
\text { sealing and no leakages }\end{array}$ & 0.770 & 0.631 & 0.651 \\
2. & $\begin{array}{l}\text { Requirement item are correctly } \\
\text { printed on the label. }\end{array}$ & 0.449 & 0.528 & \\
\hline & It is observed from the above table & Amin (2014) conducted a research to assess
\end{tabular}
that, the attributes of Aroma milk such as 'proper sealing' and 'label information' constituted factor 6 are characterized as "Packaging". The higher factor loading of the attributes indicate that factor 6 under lies that variable. The higher value of communality for the two attributes indicates that higher amount of variance is explained by the extracted factors. The included two variables explain this factor to the extent of 65.1 percent. Akbay and Tiryaki (2009) analyzed unpacked and packed milk preferences in Samsun province of Turkey. The results indicated that better educated household head, higher income households, younger and female household head and people who agreed with 'unpacked milk is not healthy' consumed more packed fluid milk than did others. Moreover, consumers who agreed with statement "price of packed milk is expensive compare to unpacked milk' were less likely to consume packed fluid milk than did others. Ahmed and the impact of packaging on product purchase. According to the finding of the research study, it was observed that the packaging was the most important factor. It was further concluded that the packaging elements like its color, packaging material, design of wrapper and innovation were more important factors when consumers making any buying decision. Finally, it has also been concluded that the Packaging is one of the most important and powerful factor, which influences consumer's purchase decision.

$\mathbf{H}_{0}$ 2: The above finding proves the second hypothesis that the most important expectation of the consumers is the good aroma of Aroma milk.

Motivational factors for purchase of aroma milk

Factor analysis on these attributes relating to purchase decision factors for Aroma milk are identified under six buying decision and the results are presented in the Table 8 .

Table 8 Motivational factors for purchase of aroma milk

\begin{tabular}{clcccc}
\hline S. No & \multicolumn{1}{c}{ Factors } & $\begin{array}{c}\text { Number of } \\
\text { Variables }\end{array}$ & $\begin{array}{c}\text { Eigen } \\
\text { Value }\end{array}$ & $\begin{array}{c}\text { Percentage of } \\
\text { Variation }\end{array}$ & $\begin{array}{c}\text { Cum. Percentage of } \\
\text { variation }\end{array}$ \\
\hline 1. & Quality & 6 & 6.094 & 32.072 & 32.07 \\
2. & Healthy & 4 & 1.774 & 9.335 & 41.41 \\
& Consciousness & 3 & 1.541 & 8.109 & 49.52 \\
3. & Price & 2 & 1.307 & 6.879 & 56.39 \\
4. & Availability & 2 & 1.071 & 5.637 & 62.03 \\
5. & Door Delivery & 2 & 1.052 & 5.539 & 6.57 \\
6. & Packaging & It is observed from the Table 8, that the six factors such as quality, healthy \\
& 69
\end{tabular}


conscious, price, availability, door delivery and packaging were extracted out of nineteen attributes. These factors account for about 67.57 percent of variance in the data. Eigen value for the first factor 'quality' is 6.094 which indicate that the factor contains very high in formation than the other factors. The first factor, 'quality' provides the maximum in sights of purchase decision of Aroma milk in the study. It is very important factor, because the consumers prefer to purchase Aroma milk on the basis of quality. To improve this situation, the industry will give more importance to the attributes concerning the "quality" of milk. The second important factor called "healthy conscious" accounts for 9.335 percent variance.
The Eigen value of this second factor is 1.774 and it show that people are health conscious about the product they purchase in day-to-day life. The third and fourth factors 'price' and 'availability' account for 8.109 percent and 6.879 variance with the Eigen value of 1.541 and 1.307 respectively. It is certain that consumers give more preference to pricing and for its quality level, also the product being delivered at right time. The fifth and the sixth factors, 'door delivery' and 'packaging' account for 5.637 percent and 5.539 variance with the Eigen value of 1.017 and 1.052 respectively. Door step delivery and packaging is also important in making purchase decision for Aroma milk.

Table 9 Results of KMO and Bartlett's Test

$\begin{aligned} & \text { Kaisser-Meyer- Olkin measure of sampling ad } \\ & \text { Approx Chi-S } \\ & \text { Bartlett's Test of }\end{aligned}$
$\begin{aligned} & \text { Degree of free } \\ & \text { Significance }\end{aligned}$
High value of Kaiser-Mayer-Olkin
(KMO) test of sampling adequacy (0.882)
indicates the correlation between the pairs of
variables explained by other variable sand
thus factor analysis considered be
appropriate in this model.

Motivational factors influencing the overall decision behaviour of the consumers

The multiple regression analysis has been executed to analyse the motivational factors among the Aroma milk consumers and the overall score on purchase decision behaviour is treated as dependent variable whereas motivational factors such as quality, health conscious, price, availability, door delivery and packaging are taken as in

0.882
11020.828
171
0.000

dependent variables. The results of regression co- efficient of the independent variable are mentioned be low in the Table 10 .

Table10 Impact of motivational factors on consumer decision behaviour

\begin{tabular}{clc}
\hline $\begin{array}{c}\text { S. } \\
\text { No }\end{array}$ & Motivational Factors & $\begin{array}{c}\text { Regression Co- } \\
\text { efficient }\end{array}$ \\
\hline 1. & Quality & $0.562^{* *}$ \\
2. & Healthy & $0.250^{* *}$ \\
& Consciousness & $-0.003^{\mathrm{NS}}$ \\
3. & Price & $0.249^{*}$ \\
4. & Availability & $0.037^{\mathrm{NS}}$ \\
5. & Door Delivery & $0.327^{* *}$ \\
6. & Packaging & $3.129^{* *}$ \\
& Constant & 0.912 \\
& $\quad \mathrm{R}^{2}$ & $331.474^{* *}$ \\
\hline
\end{tabular}


(** - Significant at 1 percent level, * - Significant at 5 percent level, NS - Not Significant)

It can be seen from the Table 10, that the regression analysis among the sample respondents, the significantly influencing motivational factors are quality, health conscious, availability and packaging. An increase in quality, healthy conscious, availability and packaging results an increase on consumer decision behaviour. The analysis reveals that an increase in the consumer decision behaviour by $0.562,0.250 .0 .249$ and 0.327 respectively from its mean level. The factors price and door delivery were not considered as significant. The impact changes on motivational factors explain the change son decision behavior to the extent of 91.20 percent, sinceit $\mathrm{R}^{2}$ is 0.912 .

Similar to the present study, Jothi (2013) conducted a study on consumer behavior of Aavin. The study focused on consumer behavior is a subset of consumer behaviors, which is concerned with decisions that lead up to the act of purchase. It could be the influence of the variable price brand image, quality of the product, regularity of service. The study attempts to bring out the factors leading to the purchase behavior and perception of consumers in buying Aavin milk. The consumers are satisfied with quality of Aavin brand compared to other brands. Robinson (1999) conducted a research on the customer preference towards dairy products. The study made an attempt to identify the customer's preference towards dairy products and to know about the factors which influence the selection of different brands of dairy products. The study revealed that the company should make survey to know the expectations of the consumers and produce that product in the manner so as to attract more customers towards their brand and advertisement can be done through mass media to increase sales and to educate customers about the product. Elangovan \& Gomatheeswaran (2015) focused on consumer behavior towards various brands of milk and milk products. Consumers' lifestyles are influenced by number of factors. Like culture, subculture, values, demographic factors, social status, reference groups, household and also the internal makeup of the consumer, which are emotions, personality motives of buying, perception and learning. The study was examining the differences in consumer's behavior with socio and economic characteristics towards brand selection.

\section{Conclusion}

Aroma milk has a good reputation among the customers, so it can be extended supplying products towards the customer demand for and availability in markets must maintained for the consumer to say in the same Aroma brand. Based on the findings of the study, there are still a large portion of consumers not satisfied with Aroma brand. Industry can target that segment and use it as an opportunity to expand their sales by satisfying those consumers also by retaining the existing consumers. For that they have to make their quality and availability their utmost importance than any other factors.

\section{Acknowledgment}

The authors are thankful to Professor and Head, Department of Agricultural and Rural Management, Tamil Nadu Agricultural 
University for providing facilities and advice required for this research study. We thank Mrs. Vijayalakshmi, CEO, Sri Mahalakshmi Dairy (Aroma Milk) for her co-operationand accepting our permission in thie research work.

\section{References}

Kariyawasam S, Jayasinghe-Mudalige U \& Weerahewa J. 2006. Assessing Consumer Perceptions Towards Attributes of Food Quality: The Case of Consumption of Tetra-Packed Fresh Milk in Sri Lanka. Canadian Agricultural Economics Society Annual Meeting. Montreal, Quebec.

Elangovan N \& Gomatheeswaran M. 2015. A study on consumer behaviour towards various brands of milk and milk products with special reference to Thudiyalur town at Coimbatore district in Tamil Nadu. International Journal of Multidisciplinary Research and Development, 595 - 601.
Ahmed RR, Pramar V \& Amin AM. 2014. Impact of Product Packaging on Consumer's Buying Behavior. European Journal of Scientific Research, 120 (2): 145-157.

Jothi MC. 2013. A study on consumer behaviour of aavin milk in bhel township: trichy. International Journal of Advance Research in Computer Science and Management Studies, 1 (4): 34-39.

Rangasamy N \& Dhaka JP. 2008. Marketing Efficiency of Dairy Products for Cooperative and Private Dairy Plants in Tamil Nadu - A Comparative Analysis, Agricultural Economics Research Review, 21: 235-242.

Robinson S. 1999. Measuring service quality: current thinking and future requirements. Marketing Intelligence and Planning, 17(1): 21-32. 